\title{
Late-Night Snacking Decreases Nocturnal Secretion of Growth Hormone
}

\author{
Hiroko Kodama, Kazuoki Kubota, Mamoru Hata, Yutaka Nakazato and Toshiaki Abe \\ Department of Pediatrics, Teikyo University School of Medicine, Tokyo, Japan
}

\begin{abstract}
The effect of snacking before going to sleep on the nocturnal secretion of GH was investigated in 7 children with non-GH deficiency short stature. Each child was tested on two nights: on one night, the child ate a snack before going to bed, but on the other night, the child did not. Serum GH concentrations were measured every 20 min during the first $3 \mathrm{~h}$ of sleep. GH concentrations in urine collected the following morning were also examined. Mean and maximum serum GH values, and urinary GH concentrations were lower in all of the children when they had eaten a snack before going to bed.
\end{abstract}

Key words: late-night snacking, nocturnal secretion of GH, urinary GH

\section{Introduction}

The dietary habits of people in certain developed countries seem to be changing. Late-night snacking is becoming more popular. Many people stay up until late at night and eat before going to bed. This habit is also becoming popular among children. This habit may affect nocturnal secretion of $\mathrm{GH}$, because $\mathrm{GH}$ secretion is known to be affected by glucose and protein intakes. The greatest amounts of GH are spontaneously secreted during sleep, especially during the first few hours after the onset of sleep (1-3). We therefore examined the effects of late-night snacking on the nocturnal secretion of $\mathrm{GH}$ in children.

Received: April 12, 1994

Accepted: October 2, 1996

Correspondence: Dr. Hiroko Kodama, Department of Pediatrics, Teikyo University School of Medicine, 11-1, Kaga-2, Itabashi-ku, Tokyo 173, Japan

\section{Materials and Methods}

The tests were performed on 7 children (height <-2.0SD; mean, - 2.4SD) diagnosed as being of short stature with normal GH secretion on the basis of $\mathrm{GH}$ provocation tests. Informed consent was obtained from both the children and their parents. One of the children had Turner's Syndrome, but the others had no physical or laboratory abnormalities except their short stature. GH concentrations were measured for 2 nights in each child, one night after eating a snack within $2 \mathrm{~h}$ of going to bed, and the other without it. Approximately $300 \mathrm{kcal}$ of food (a piece of bread and a glass of juice) was given as the snack. The food consisted of about $50 \mathrm{~g}$ of carbohydrate, $8 \mathrm{~g}$ of protein and $7 \mathrm{~g}$ of fat. They went to bed at $9 \mathrm{pm}$. On both nights, the serum concentrations of $\mathrm{GH}$ and glucose were measured every $20 \mathrm{~min}$ for $3 \mathrm{~h}$ after the children fell asleep. Children passed urine before going to bed, and the first urine the next morning was collected. 
GH concentrations in the serum and urine were measured by a double-antibody radioimmunoassay and an enzyme immunoassay (4), respectively.

\section{Results}

Table 1 shows maximum and mean serum $\mathrm{GH}$ values, and urinary $\mathrm{GH}$ concentrations. When the children did not eat a snack, the serum GH concentrations peaked during the first $3 \mathrm{~h}$ of sleep in all of the children. When the snack was eaten, a GH peak was also observed, but the maximum value for each child was significantly lower than that without the snack. The mean serum $\mathrm{GH}$ value during the first $3 \mathrm{~h}$ of sleep also decreased in all of the children when they had eaten a snack. When the snack was eaten, the urinary GH concentration on the following morning was also lower in all the children. After the snack was eaten, serum glucose levels during the first $3 \mathrm{~h}$ of sleep were between 85 and 134 $\mathrm{mg} / \mathrm{dl}$, and slightly higher than that without the snack (80-112 mg/dl).

\section{Discussion}

There have been only a few reports on the relationship between $\mathrm{GH}$ secretion and meals. Costin et al. (3) reported that GH secretion increases after meals, whereas others found no relationship between them $(5,6)$, but these findings were based on serum GH concentrations after meals compared with before meals. In this study, the effect of snacking on GH secretion was evaluated by comparing the values in each child when a snack was eaten and when it was not. When the children did not eat a snack, the maximum $\mathrm{GH}$ values were similar to the levels of normal children, as reported previously (2). After the snack was eaten, however, the serum values decreased to the levels shown by patients with GH neurosecretory dysfunction (2). Our results showed that the serum GH values during the first $3 \mathrm{~h}$ of sleep were significantly lower when the snack was eaten. This was also true for urinary $\mathrm{GH}$ concentrations on the following morning. GH concentrations in early morning urine have been reported to be correlated with nocturnal GH secretion (7). Our results there-

Table $1 \mathrm{GH}$ concentrations in the serum and urine of 7 children with and without late-night snacking

\begin{tabular}{|c|c|c|c|c|c|c|c|c|}
\hline \multirow[t]{3}{*}{ Case } & \multirow{3}{*}{$\begin{array}{l}\text { Age } \\
(Y)\end{array}$} & \multirow[t]{3}{*}{ Sex } & \multicolumn{4}{|c|}{ Serum GH conc. (ng/ml) } & \multirow{2}{*}{\multicolumn{2}{|c|}{$\frac{\text { Urine GH conc. }}{\text { (pg/mg creatinine) }}$}} \\
\hline & & & \multicolumn{2}{|c|}{ Maximum } & \multicolumn{2}{|c|}{ Mean } & & \\
\hline & & & No snack & Snack & No snack & Snack & No Snack & Snack \\
\hline 1 & 6 & M & $30.0(5)$ & $8.2(8)$ & 15.9 & 3.2 & $33.0(6), 24.0(10)$ & $13.2(9)$ \\
\hline 2 & 10 & $\mathrm{~F}$ & $12.0(3)$ & $4.8(1)$ & 6.0 & 1.9 & $12.9(3), 13.7(4)$ & $6.7(2)$ \\
\hline 3 & 11 & $\mathrm{~F}$ & $66.0(3)$ & $12.0(12)$ & 28.9 & 5.8 & $62.3(3), 37.2(4)$ & $12.0(13)$ \\
\hline 4 & 11 & M & $20.0(4)$ & $15.0(8)$ & 9.8 & 4.8 & $25.0(5), 27.7(8)$ & $9.6(9)$ \\
\hline 5 & 12 & M & $29.0(1)$ & $19.0(4)$ & 16.3 & 6.6 & $33.9(2), 36.0(6)$ & $24.7(5)$ \\
\hline 6 & 12 & $\mathrm{~F}$ & $16.0(1)$ & $6.4(4)$ & 8.4 & 3.3 & $24.8(2), 28.3(6)$ & $14.3(5)$ \\
\hline 7 & 14 & M & $27.0(3)$ & $14.0(2)$ & 7.5 & 4.0 & $20.7(2), 25.5(4)$ & $13.2(3)$ \\
\hline $\begin{array}{r}\text { Mean } \\
\pm S D\end{array}$ & & & $\begin{array}{l}28.6 \\
\pm 16.5\end{array}$ & $\begin{array}{l}11.3^{*} \\
\pm 4.7\end{array}$ & $\begin{array}{l}13.3 \\
\pm 7.4\end{array}$ & $\begin{array}{l}4.2^{*} \\
\pm 1.5\end{array}$ & $\begin{array}{l}28.9 \\
\pm 11.7\end{array}$ & $\begin{array}{l}13.4^{*} \\
\pm 5.2\end{array}$ \\
\hline
\end{tabular}

The numbers in parentheses indicate the day after admission in which the test was performed. Urinary GH concentrations without a snack were determined in two different mornings in each case. Statistical analysis was carried out with Wilcoxon's rank test. $*<0.005$ 
fore indicate that eating food prior to going to bed decreases the nocturnal secretion of GH. The snack in our study was mainly carbohydrate. Ingestion of glucose is thought to promote the secretion of somatostatin, which inhibits GH secretion (9). On the other hand, the spontaneous increase in GH secretion during the night has been reported to be due to reduced release of somatostatin (8). Our results, along with these findings, suggest that the normal reduction in somatostatin during sleep is impaired by the intake of glucose in the snack, and therefore late-night snacking decreases nocturnal secretion of GH. The mean GH concentration during the first three hours of sleep and/or GH concentration in the early morning urine can be used to evaluate the level of nocturnal GH secretion (7, $10,11)$. Our results indicate that late-night snacking might cause false-negative data; that is, children with normal GH secretion might be misdiagnosed with a GH neurosecretory dysfunction if they are tested after eating a snack or meal. Late-night snacking should therefore be avoided when nocturnal GH secretion is examined.

\section{Acknowledgements}

This work was supported in part by a research grant from the Growth Science Foundation in Japan.

\section{References}

1. Costin G, Kaufman FR. Growth hormone secretory patterns in children with short stature. J Pediatr 1987; 110: 362-8.

2. Shulman DI, Bercu BB. Evaluation of growth hormone secretion: Provocative testing vs endogenous 24-hour growth hormone profile. Acta Pediatr Scand [Suppl] 1987; 337: 61-71.
3. Costin G, Kaufman FR, Brasel JA. Growth hormone secretory dynamics in subjects with normal stature. J Pediatr 1989; 115: 537-44.

4. Hasida $\mathrm{S}$, Ishikawa $\mathrm{E}$, Kato $\mathrm{Y}$, Imura $\mathrm{H}$, Mohri Z, Murakami Y. Human growth hormone (hGH) in urine and its correlation to serum hGH examined by a highly sensitive sandwich enzyme immunoassay. Clin Chim Acta 1987; 162: 229-35.

5. Plotnick LP, Thompson RG, Kowarski A, Lacerda L, Migeon CJ, Blizzard RM. Circandian variation of Integrated concentration of growth hormone in children and adults. J Clin Endocrinol Metab 1975; 40: 240-6.

6. Miller JD, Tannenbaum GS, Colle E, Guyda HJ. Daytime pulsatile growth hormone secretion during children and adolescence. J Clin Endocrinol Metab 1982; 55: 989-94.

7. Sukegawa I, Hizuka N, Takano K, Asakawa K, Horikawa $\mathrm{R}$, Hashida $\mathrm{S}$, et al. Measurement of nocturnal urinary growth hormone values. Acta Endocrinol (Copenh) 1989; 121: 290-6.

8. Ghigo E, Arvat E, Mondardini A, Cappa M, Muller $\mathrm{EE}$, Cammani F. Failure of pyridostigmine to increase both basal and GHRH-induced GH secretion in the night. Acta Endocrinol (Copenh) 1990; 122: 37-40.

9. Shibasaki T, Masuda A, Hotta M, Yamauchi N, Hizuka N, Takano K, et al. Effects of ingestion of glucose on GH and TSH secretion: Evidence for stimulation of somatostatin release from the hypothalamus by acute hyperglycemia in normal man and its impairment in acromegalic patients. Life Science 1988; 44: 431-8.

10. Sanayama K, Noda H, Konda S, Ikeda F, Murata A, Sasaki N, et al. Spontaneous growth hormone secretion and plasma somatomedin-C in children of stature. Endocrinol Japan 1987; 34: 627-33.

11. Kida K, Ito T, Hayashi M, Kaino Y, Goto Y, Ikeuchi $\mathrm{M}$, et al. Urinary excretion of human growth hormone in children with short stature: Correlation with pituitary secretion of human growth hormone. J Pediatr 1992; 120: 233-7. 